\title{
Physiological Determinants and Yield Components as Influenced by High Density Planting System in Cotton
}

\author{
T. Raghavendra* and Y. Rama Reddy \\ Regional Agricultural Research Station, Acharya N G Ranga Agricultural University, \\ Nandyal-518501, A.P. India \\ *Corresponding author
}

\section{A B S T R A C T}

\begin{abstract}
High density planting system have the potential for increased yields in high yielding, high input production systems. To attain higher yields in high density planting system in cotton relative to conventional spaced cotton must depend on increased biomass production or partitioning to boll. The present experiment was conducted for two consecutive seasons to analyse the morpho- phenological characters and leaf $\mathrm{CO}_{2}$ exchange rates of cotton in five different spacings i.e. $45 \times 10 \mathrm{~cm}^{2}, 45 \times 15 \mathrm{~cm}^{2}, 45 \times 20 \mathrm{~cm}^{2}, 45 \times 30 \mathrm{~cm}^{2}$ and $60 \times 30 \mathrm{~cm}^{2}$ in two American cotton genotypes i.e NDLH1938 and NH 615.Wider spacing produced significantly higher growth attributes like boll number (26.3) sympodia (12.4), leaf photosynthetic rate $\left(26.25 \mu \mathrm{mol} \mathrm{m} \mathrm{mec}^{-1}\right)$ at peak bloom stage, stomatal conductance (422.58 $\mu \mathrm{mol} \mathrm{H}_{2} \mathrm{O} \mathrm{m}^{-2} \mathrm{sec}^{-1}$ ) and transpiration rate $\left(4.89 \mathrm{mmol} \mathrm{H}_{2} \mathrm{O} \mathrm{m}^{-2} \mathrm{sec}^{-1}\right.$ ) at boll formation stage. While in closer spacings early square formation and flowering was observed, but dry matter partitioning was slower and total biomass production was significantly low $(78.6 \mathrm{gm})$ and consequently the boll weight was less $(3.2 \mathrm{gm})$ leading to decreased economic yield. The effect of plant density on leaf area index is additive and varied with plant density from about 4.24- 5.78. Even though the density of plants was increased there is seldom increment in kapas yield as the partitioning is affected due to decrease in leaf $\mathrm{CO}_{2}$ exchange rates.
\end{abstract}

\section{Introduction}

Cotton (Gossypium hirustum L.) is grown globally as a major source of natural fiber and is considered as white gold. In India cotton is grown over an area of 122.38 lakh hectares with production of 361 lakh bales with productivity of $501 \mathrm{~kg}$ lint/ha. Among the states Maharashtra, Gujarat and Telangana were the major cotton growing states covering around $70.45 \%$ (86.22 lakh hectare) in area under cotton cultivation and $62.60 \%$ (226 lakh bales) of cotton production in India (AICRP Annual Report cotton, 2018-19). In India, the seed cotton yield per unit area is far below than many other cotton growing countries in the world. Among the various factors responsible for low yield of cotton crop in the country are low plant population and use of low potential varieties. 
Cotton has indeterminate growth habit, the crop shows morphological adaptations to its growing environment such as modification in canopy architecture in response to plant population density. Morphological adaptations in terms of canopy development, light interception, source sink relationship and assimilates partitioning are the major determinant of lint yield and quality (Yang et al., 2014).

The manipulation of row spacing, plant density and the spatial arrangements of cotton plants, for obtaining higher yield have been attempted earlier by many researchers. The concept on high density cotton planting, more popularly called Ultra Narrow Row (UNR) cotton was initiated by Briggs et al., (1967).

The availability of compact genotypes, acceptance of weed and pest management technologies including transgenics, mechanized harvesting and widespread application of growth regulators have made these high density cotton production systems successful in many countries (Rossi et al., 2004). These advances lead to resurgence of interest in high density, ultra narrow cotton production systems, particularly in high yielding systems than in the past. Clawson et al., 2006 reported that higher plant population resulted in reduced number of bolls per plant and more bolls per unit area.

Reduced number of bolls resulted in earlier maturity due to shorter flowering and fruiting window. Growth analysis and physiological determinants frame work (Coleman et al., 1994) were used to identify the key factors in influencing yield and maturity of high density planting genotypes and conventionally spaced cotton in high input system. The objective of the study was to investigate the effect of different planting densities on plant growth and its attributing characters and $\mathrm{CO} 2$ gas exchange parameters.

\section{Materials and Methods}

The field experiment was conducted in 2016 and 2017 at Acharya N G Agricultural University, Regional Agricultural Research Station, Nandyal $\left(15^{0} 27^{\mathrm{N}}\right.$ and $\left.78^{0} 28^{\prime} \mathrm{E}\right)$ of Andhra Pradesh. The soil of the experimental field is black cotton soil, with $\mathrm{P}^{\mathrm{H}} 8.3$ and EC $0.26 \mathrm{dS}^{-\mathrm{m}}$ The experiment was laid out in Split plot design, replicated three times with five different spacings i.e. $45 \times 10 \mathrm{~cm}^{2}, 45 \times 15$ $\mathrm{cm}^{2}, 45 \times 20 \mathrm{~cm}^{2}, 45 \times 30 \mathrm{~cm}^{2}$ and $60 \times 30$ $\mathrm{cm}^{2}$ as main plots and two American cotton genotypes i.e. NDLH1938 and NH 615 as subplots.

\section{Photosynthetic attributes}

Gaseous exchange parameters viz., photosynthetic rate $(\mathrm{Pn})$, stomatal conductance $(\mathrm{gs})$, and transpiration rate $(\mathrm{Tr})$ of cotton leaves from 5 selected plants per plot were determined with a $C I-310$ portable photosynthesis system (CID, Inc., Camas, WA, USA).Canopy photosynthetic rate was measured between 9:00 to 11.00AM on clear days and $4^{\text {th }}$ fully expanded leaf from the apex on the main stem at $50 \%$ flowering were recorded. The assimilation chamber was placed between the rows and the chamber was covered to prevent air leakage from around the bottom of the chamber. The $\mathrm{CO}_{2}$ concentrations inside the chambers ranged from 350-400ppm during the gas sampling times. The air temperature and relative humidity were at ambient levels

\section{Leaf morphological attributes}

Five plants were randomly selected in each plot for determination of specific leaf area, and leaf area index was calculated on ground area basis. After drying at $80^{\circ} \mathrm{C}$ to a constant weight, samples were weighed, and the yields of seed cotton and stalk (root, stem, branches, carpels and remnant leaves) were recorded. 
Dry weights of reproductive organs (squares, flowers, green and mature bolls) were weighed after drying at least for $48 \mathrm{~h}$ at $80^{\circ} \mathrm{C}$.

\section{Statistical Analysis}

All data recorded were analyzed with the help of analysis of variance (ANOVA) technique (Gomez and Gomez 1984) for split plot using STAR (Statistical tool for agricultural research, IRRI).

\section{Results and Discussion}

High density planting system has significant affect on canopy architecture and growth of the crop. Plant height was $(146.3 \mathrm{~cm})$ at $45 \mathrm{x}$ $10 \mathrm{~cm}^{2}$ and at significantly the plant height was less $(128.3 \mathrm{~cm})$ at $60 \times 30 \mathrm{~cm}^{2}$. The possible explanation for more height in close spacings may be due to increased competition for sunlight as the architecture of the canopy is more of vertical orientation. Paslawar et al., 2015 reported that plant height was significantly highest in narrow row planting i.e $45 \times 10 \mathrm{~cm}^{2}$.

Boll number and boll weight were significantly low in closer spacings compared to wider spacings. Higher boll number (26.3) and boll weight (4 gm) were recorded in $60 \mathrm{x}$ $30 \mathrm{~cm}^{2}$ as wider spacings have more photosynthetic area and more partitioning compared to narrow spacings as light is a limiting factor (Table 1). Ramesh et al., 2016 reported that higher boll number and boll weight were observed in wider row spacings under high density planting system. Sympodial branches are significantly lower in closer spacings i.e 7.8 at $45 \times 10 \mathrm{~cm}^{2}$ compared to wider spacings 12.4 at $60 \times 30$ $\mathrm{cm}^{2}$ and with increase in spacing between the plants the sympodia per unit plant were increased. The results are in agreement with the results of Manjula and shashidhara 2017, who reported that number of monopodia, sympodia and dry weights of the plant were significantly higher with wider spacings.

In the present study, increased plant density significantly decreased biological yield, and there was a significant effect of plant density with genotypes on cotton yield. Leaf area index (LAI) varied with plant density from about 4.24- 5.78. The effect of plant density on LAI is additive. Lili mao et al., (2014) reported that Leaf area index was affected by plant densities. LAI varied with plant density, from about 2.5 to 5.0 and the reduction of LAI was readily compensated at higher plant density. Thus, it is very important to decrease plant density for yield stability by increasing biological yield. Reasonable changes in leaf area index are important guarantee of high cotton yield (Dong et al., 2006).

Specific leaf area is mostly affected by changes in light conditions as plant develops as it plays a key role in morphological acclimation to changes in the spatial distribution of light within plant canopies. Efficient light harvesting plays a prominent role in for plant growing in dense stand. Because of the less assimilates production in high density crop the upper canopy leaves are thin and more specific leaf area (SLA). In the current research low SLA (15.34) at peak vegetative stage in $60 \times 30 \mathrm{~cm}^{2}$ was observed. Canopy with normal spacings have thick leaves because of greater advantage of light and eventually thick leaves with low SLA have greater photosynthetic capacity than thin leaves with high SLA (Hesheng Yao et al., 2016).

The higher rate of biomass accumulation in the high density crop early in the season but not later in the season compared to conventionally spaced crop was most likely due to increased competition between the plants for resources limiting growth of plants in high density crop earlier than the 
conventionally spaced crop. Despite an increase in population the final biomass production was similar with wider spacings. It is in the range of $78.6 \mathrm{~g} / \mathrm{plant}$ to $93.8 \mathrm{~g} / \mathrm{plant}$. Individually the plants were smaller and with less biomass produced per plant indicating that there is a limitation in assimilate for growth and development due to competition between the plants.

Gwathmey and clement (2010) reported that ultra-narrow row cotton had low boll set and lower starch reserves as compared with conventionally spaced rows, supporting the hypothesis that photosynthetic assimilate may be limiting in ultra-narrow row plants.

\section{Gas exchange measurements}

Photosynthetic rate of cotton plant was significantly affected by plant density during in all growth stages and maximum at peak bloom phase (Table 2). Among the spacings photosynthetic rate was maximum i.e. 25.65 and $26.25\left(\mu \mathrm{mol} \mathrm{m} \mathrm{sec}^{-1}\right)$ at $60 \times 30 \mathrm{~cm}^{2}$ both at squaring and peak bloom phases and decreased at boll formation stage i.e. 25.12 $\left(\mu \mathrm{mol} \mathrm{m} \mathrm{m}^{-2} \mathrm{sec}^{-1}\right)$. Aziz khan et al., 2017 reported that photosynthetic rate increased as the crop transitioned from one stage to another but it decreased during boll opening stage and plants sown early exhibited $10 \%$ and $16 \%$ higher photosynthetic rate than late sown plants at squaring and first bloom stage, respectively.

Stomatal conductivity was higher at wider spacings comparatively to closer spacings as the interception of light played a key role in stomata opening and closing, which is directly correlated to the water use efficiency and exacerbates the dry matter partitioning and photosynthetic assimilates production by decrease in vapour pressure deficit (VPD).

Table.1 Plant morpho-phenological characters as influenced by different spacings and varieties

\begin{tabular}{|c|c|c|c|c|c|c|c|c|}
\hline Treatments & $\begin{array}{l}\text { Plant } \\
\text { height } \\
(\mathrm{cm})\end{array}$ & $\begin{array}{c}\text { Boll } \\
\text { Number }\end{array}$ & $\begin{array}{c}\text { Boll } \\
\text { weight } \\
\text { (gm) }\end{array}$ & $\begin{array}{c}\text { No. of } \\
\text { sympodia/ } \\
\text { plant }\end{array}$ & $\begin{array}{c}\text { Leaf } \\
\text { area } \\
\text { index }\end{array}$ & $\begin{array}{l}\text { Specific } \\
\text { leaf area } \\
(\mathrm{cm} 2 / \mathrm{gm})\end{array}$ & $\begin{array}{c}\text { Biomass } \\
\text { g/ plant }\end{array}$ & $\begin{array}{c}\text { Kapas } \\
\text { yield } \\
\mathrm{kg} / \mathrm{ha}\end{array}$ \\
\hline \multicolumn{9}{|l|}{ Spacings } \\
\hline $45 \times 10 \mathrm{~cm}$ & 146.3 & 15.2 & 3.2 & 7.8 & 5.78 & 20.37 & 78.6 & 1550 \\
\hline $45 \times 15 \mathrm{~cm}$ & 135.8 & 16.4 & 3.3 & 8.1 & 4.80 & 17.20 & 77.4 & 1773 \\
\hline $45 \times 20 \mathrm{~cm}$ & 137.9 & 18.6 & 3.6 & 8.2 & 4.34 & 15.58 & 81.2 & 1874 \\
\hline $45 \times 30 \mathrm{~cm}$ & 138.2 & 21.2 & 3.8 & 10.5 & 4.10 & 15.60 & 84.2 & 1890 \\
\hline $60 \times 30 \mathrm{~cm}$ & 128.3 & 26.3 & 4.0 & 12.4 & 4.24 & 15.34 & 93.8 & 2211 \\
\hline S.Em \pm & 4.2 & 0.97 & 0.03 & 0.52 & 0.23 & 0.91 & 6.1 & 117 \\
\hline CD at $5 \%$ & 16 & 3.12 & 0.08 & 1.74 & 1.3 & 4.2 & NS & 424 \\
\hline \multicolumn{9}{|l|}{ Varieties } \\
\hline NDLH1938 & 121 & 26.8 & 3.9 & 12.4 & 5.2 & 13.2 & 95.4 & 2261 \\
\hline NH615 & 95 & 32.4 & 3.7 & 15.8 & 4.5 & 14.2 & 93.2 & 2566 \\
\hline S.Em \pm & 2.6 & 1.1 & 0.02 & 0.42 & 0.19 & 0.52 & 1.84 & 214 \\
\hline CD at $5 \%$ & 8.1 & 3.9 & 0.06 & 1.34 & 0.55 & NS & NS & NS \\
\hline \multicolumn{9}{|l|}{ Interaction } \\
\hline S.Em \pm & 6.7 & 1.2 & 0.18 & 0.45 & 0.15 & 0.2 & 5.8 & 110 \\
\hline CD at $5 \%$ & NS & NS & NS & NS & NS & NS & NS & NS \\
\hline
\end{tabular}

NS- Non Significant 
Table.2 Leaf $\mathrm{CO} 2$ gas exchange parameters as influenced by different spacings and varieties

\begin{tabular}{|c|c|c|c|c|c|c|c|c|c|}
\hline \multirow[t]{2}{*}{ Treatments } & \multicolumn{3}{|c|}{$\begin{array}{l}\text { Photosynthetic rate } \\
\left(\mu \mathrm{mol} \mathrm{m} \mathrm{sec}^{-1}\right)\end{array}$} & \multicolumn{3}{|c|}{ 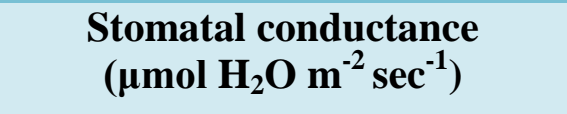 } & \multicolumn{3}{|c|}{$\begin{array}{l}\text { Transpiration rate } \\
\left(\mathrm{mmol} \mathrm{H}_{2} \mathrm{O} \mathrm{m} \mathrm{sec}^{-1}\right)\end{array}$} \\
\hline & $\begin{array}{l}\text { Squaring } \\
\text { 40DAE }\end{array}$ & $\begin{array}{c}\text { Peak } \\
\text { bloom } \\
\text { 90DAE }\end{array}$ & $\begin{array}{c}\text { Boll } \\
\text { formation } \\
\text { 120DAE }\end{array}$ & $\begin{array}{l}\text { Squaring } \\
\text { 40DAE }\end{array}$ & $\begin{array}{c}\text { Peak } \\
\text { bloom } \\
\text { 90DAE }\end{array}$ & $\begin{array}{c}\text { Boll } \\
\text { formation } \\
\text { 120DAE }\end{array}$ & $\begin{array}{l}\text { Squaring } \\
\text { 40DAE }\end{array}$ & $\begin{array}{c}\text { Peak } \\
\text { bloom } \\
90 \text { DAE }\end{array}$ & $\begin{array}{c}\text { Boll } \\
\text { formation } \\
\text { 120DAE }\end{array}$ \\
\hline \multicolumn{10}{|l|}{ Spacings } \\
\hline $45 \times 10 \mathrm{~cm}$ & 23.12 & 23.57 & 22.15 & 396.54 & 406.54 & 411.25 & 3.01 & 3.55 & 3.81 \\
\hline $45 \times 15 \mathrm{~cm}$ & 23.45 & 24.12 & 23.45 & 401.25 & 411.25 & 418.51 & 3.11 & 3.37 & 3.97 \\
\hline $45 \times 20 \mathrm{~cm}$ & 23.81 & 24.25 & 23.64 & 405.28 & 415.28 & 419.25 & 3.81 & 4.18 & 4.21 \\
\hline $45 \times 30 \mathrm{~cm}$ & 24.35 & 25.24 & 24.41 & 408.65 & 418.65 & 421.74 & 4.01 & 4.27 & 4.41 \\
\hline $60 \times 30 \mathrm{~cm}$ & 25.65 & 26.25 & 25.12 & 401.24 & 421.24 & 422.58 & 4.19 & 4.69 & 4.89 \\
\hline S.Em \pm & 0.60 & 0.45 & 0.39 & 2.41 & 3.91 & 3.45 & 0.019 & 0.023 & 0.027 \\
\hline CD at $5 \%$ & 1.25 & 1.40 & 1.18 & 7.83 & 8.17 & 8.02 & 0.057 & 0.077 & 0.081 \\
\hline \multicolumn{10}{|l|}{ Varieties } \\
\hline NDLH1938 & 24.44 & 25.14 & 26.12 & 403.25 & 410.25 & 414.25 & 3.10 & 5.10 & 4.99 \\
\hline NH615 & 25.64 & 26.14 & 27.84 & 413.15 & 433.15 & 425.36 & 3.86 & 4.86 & 5.01 \\
\hline S.Em \pm & 0.31 & 0.29 & 0.19 & 4.12 & 4.12 & 3.99 & 0.016 & 0.026 & 0.024 \\
\hline CD at $5 \%$ & 0.84 & 0.88 & 0.60 & 11.5 & 11.5 & NS & 0.051 & 0.081 & NS \\
\hline \multicolumn{10}{|l|}{ Interaction } \\
\hline S.Em \pm & 1.9 & 1.4 & 1.6 & 4.85 & 5.01 & 5.31 & 0.021 & 0.025 & 0.031 \\
\hline CD at $5 \%$ & NS & NS & NS & NS & NS & NS & NS & NS & NS \\
\hline
\end{tabular}

DAE- Days after emergence

NS- Non Significant 
Among the spacings higher stomatal conductivity $422.58 \mu \mathrm{mol} \mathrm{H}_{2} \mathrm{O} \mathrm{m} \mathrm{sec}^{-1}$ was recorded at boll formation stage in $60 \times 30$ $\mathrm{cm}^{2}$ and $421.24 \mu \mathrm{mol} \mathrm{H}_{2} \mathrm{O} \mathrm{m}{ }^{-2} \mathrm{sec}^{-1}$ at peak bloom stage. By reducing stomatal conductance to water vapor, plants minimize water loss and maintain hydration of plant cells as VPD increases. There are many studies showing that the high VPD reduces stomatal conductance thereby affecting photosynthesis and growth (Ottosen et al., 2002; Bunce, 2003; Ben-Asher et al., 2013).

Transpiration rates are widely depend on the both the plant and environmental factors. The plant factors include: root-shoot ratio, leaf area, leaf structure, and their inherent ability with respect to the opening and closing of stomata. These factors are also described as internal, their manifestation influenced by the genetic factor of plant growth and development. Transpiration rates increased from squaring to boll formation stage and higher rates were recorded in $60 \times 30 \mathrm{~cm}^{2}$ i.e $4.89 \mathrm{mmol} \mathrm{H}_{2} \mathrm{O} \mathrm{m} \mathrm{mec}^{-1}$ and among the genotypes $\mathrm{NH} 615$ recorded higher transpiration rate of $5.01 \mathrm{mmol} \mathrm{H}_{2} \mathrm{O} \mathrm{m}^{-2} \mathrm{sec}^{-1}$ .Stomata are gateway for gas exchange between the leaf and the surrounding environment.

The equilibrium of water use and carbon assimilation in leaves basically relies upon water transport through the plant and the resultant coordination with the stomatal system (Kaiser, 2009; Brodribb and Jordan, 2011). The differences in stomatal anatomy and structure influence transpiration and photosynthetic activities among the plant densities to various environmental variables.

The overall results indicated that there is no considerable influence of biomass and leaf area index on kapas yield. Specific leaf area is mostly affected by changes in light conditions as plant develops as it plays a key role in morphological acclimation to changes in the spatial distribution of light within plant canopies. Efficient light harvesting mechanism plays a key role in for plant growing in dense stand. Because of the less assimilates production in high density crop the upper canopy leaves are thin and more specific leaf area. Standardization of spacing systems and varieties to acquire higher yields is much relied on specific leaf area and $\mathrm{CO}_{2}$ gas exchange measurements

\section{Acknowledgements}

The authors wish to thank the All India Coordinated Cotton Improvement Project, RARS Nandyal for providing seed material and research facility for this study.

\section{References}

AICCIP (All India Coordinate Cotton Improvement Project) -Annual Report 2018-19.

Arizona Annual Report. University of Arizona Agricultural Extension Service, Arizona, pp. 6-7.

Aziz Khan, Ullah Najeeb, Leishan Wang, Daniel Kean Yuen Tan, Guozheng Yang, Fazal

Ben-Asher, J., Garcia, A., Flitcroft, I and Hoogenboom, G. 2013. Effect of atmospheric water vapor on photosynthesis, transpiration and canopy conductance: a case study in corn. Plant Soil and Environment 59: 549-555.

Briggs, R E, Patterson, L L and Massey G D. 1967. Within and Between-row Spacing of Cotton.

Brodribb, T J and Jordan, G J. 2011. Water supply and demand remain balanced during leaf acclimation of Nothofagus cunninghamii trees. New Phytology 192: 437-448.

Bunce, J A. 2003. Effects of water vapor pressure difference on leaf gas exchange in potato and sorghum at ambient and elevated carbon dioxide under field conditions. Field Crops Research 82: 37-47.

Clawson, E.L. 2006. Nitrogen fertilization and yield of cotton in ultra-narrow and 
conventional row spacings. Agronomy Journal 98: 72-79.

Coleman, J S., McConnaughay, K D M and Ackerly D D. 1994. Interpreting phenotypic variation in plants. Trends in Ecology and Evolution 9: 187-191.

Dong H, Li W, Tang W, Li Z, Zhang, D and Niu, Y. 2006. Yield, quality and leaf senescence of cotton grown at varying planting dates and plant densities in theYellow River Valley of China. Field Crops Research 98: 106-115.

Gwathmey, C O and Clement, J D. 2010. Alteration of cotton source-sink relations with plant population density and mepiquat chloride. Field Crops Research 116: 101107.

Hake, K and Krieg, D. 2004. Ultra Narrow Row Cotton: Global Perspective and Reduce Pesticide use Proceedings of the Technical Seminar of the 3rd Plenary Meeting of the ICAC: How to improve yields. Mumbai, India. Nov 2004, pp. 7-11.

Hesheng Yao., Yali Zhang., Xiaoping Yi., Xiangjuan Zhang and Wangfeng Zhang. 2016. Cotton responds to different plant population densities by adjusting specific leaf area to optimize canopy photosynthetic use efficiency of light and nitrogen. Field Crops Research 188: 10-16

Kaiser, H. 2009. The relation between stomatal aperture and gas exchange under consideration of pore geometry and diffusional resistance in the mesophyll. Plant Cell and Environment 32: 10911098.

Lili Mao., Lizhen Zhangb., Xinhua Zhaoc., Shaodong Liuc., Wopke vander Werfd., Siping
Manjula udikeri and Shashidhara G B. 2107. Performance of compact cotton genotypes under high density planting system at different fertilizer levels. Journal of farm science 30(4) : 460-466.

Munsif, Saif Alia and Abdul Hafeez. 2017. Planting density and sowing date strongly influence growth and lint yield of cotton crops. Field Crops Research 209: 129-135.

Ottosen, C O., Mortensen, L M and Gislerod, H R. 2002. Effect of relative air humidity on gas exchange, stomatal conductance and nutrient uptake in miniature potted roses. Euopean Journal of Horticultural Science. 67: 143-147.

Paslawar, A N., Deotalu, A S and Nemade, P W. 2015. High density planting of cotton variety $\mathrm{AKH}-081$ under rainfed condition of Vidharbha. Plant Archives, 15(2): 10751077.

Ramesh Thatikunta, Santhosh B. Janaki Ramulu Y, Lavanya B, Gouri Shankar V, Hussain S A and Reddy D V. 2016. Identification of suitable spacing and genotypes for high density planting system in cotton. The Bioscan 11(4): 2611-2614.

Rossi, J., Novick, G., Murray, J., Landivar, J., Zhang, S., Baxevanos, D., Mateos, A., Kerby, T.,

Yang, G Z., Jiao, L X., Chun, N Y and Long, Z X. 2014. Effects of Plant Density on Yield and canopy micro environment in hybrid cotton. Journal of Integrative Agriculture 13: $2154-2163$.

Zhangc., HuubSpiertzd and Zhaohu Lia. 2014. Crop growth, light utilization and yield of relay intercropped cotton as affected by plant density and a plant growth regulator. Field Crops Research 155: 67-76.

\section{How to cite this article:}

Raghavendra, T. and Rama Reddy, Y. 2020. Physiological Determinants and Yield Components as Influenced by High Density Planting System in Cotton. Int.J.Curr.Microbiol.App.Sci. 9(04): 748-754. doi: https://doi.org/10.20546/ijcmas.2020.904.089 